\title{
Potensi Ekowisata Lembu Putih Taro Sebagai Konten dan Media Pembelajaran Biologi Berbasis Kearifan Lokal Hindu Bali
}

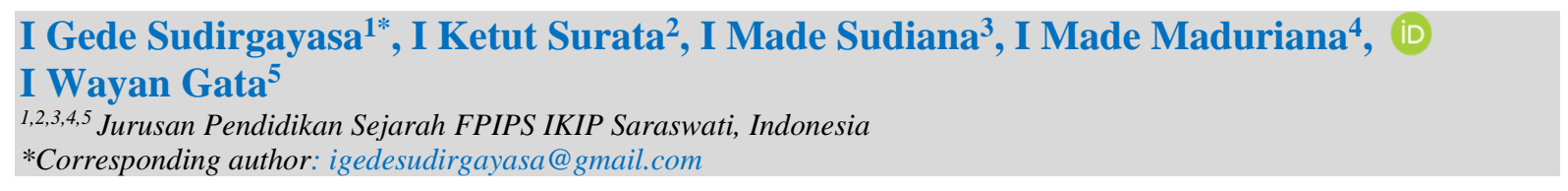

\begin{abstract}
Abstrak
Banyak guru yang belum mengintegrasikan kearifan lokal dalam pembelajaran sehingga tujuan pendidikan belum tercapai selain itu belum mengenal kearifan lokal di lingkungannya. Penelitian ini bertujuan untuk menganalisis potensi Ekowisata Lembu Putih Desa Taro sebagai media pembelajaran biologi berbasis kearifan lokal Hindu Bali. Penelitian ini merupakan penelitian deskriptif eksploratif. Data dikumpulkan melalui observasi lapangan, wawancara, dan studi dokumen. Data yang telah terkumpul dianalisis secara deskriptif kualitatif. Hasil penelitian Ekowisata Lembu Putih Taro menunjukkan: (1) dapat digunakan sebagai konten pembelajaran biologi ditinjau dari materi biologi (taksonomi, genetika, morfologi/fisiologi hewan, ekologi) dan konteks kearifan lokal yang ada di dalamnya; (2) lingkungan asli sebagai media pembelajaran berbasis kearifan lokal yang layak untuk diterapkan karena memiliki berbagai keunggulan di antaranya adalah sebagai media asli/nyata dan kontekstual sehingga mampu memberikan pengalaman langsung sehingga informasi lebih mudah dipahami dan lebih diingat, menumbuhkan kecintaan peserta didik akan kearifan lokal budayanya yang sangat bermanfaat, turut serta dalam upaya pelestarian kearifan lokal, secara tidak langsung turut serta dalam mengamalkan ajaran agama, dan meningkatkan kemampuan belajar saintifik peserta didik. Implikasi penelitian ini Ekowisata Lembu Putih Desa Taro sebagai konten dan media pembelajaran diharapkan dapat menciptakan proses pembelajaran yang lebih bermakna.
\end{abstract}

Kata kunci: Ekowisata lembu putih, kearifan lokal

\section{Abstract}

Many teachers have not integrated local wisdom in learning so that educational goals have not been achieved, besides that they are not familiar with local wisdom in their environment. This study aims to analyze the potential of White Lembu Ecotourism in Taro Village as a medium for learning biology based on Balinese Hindu local wisdom. This research is an exploratory descriptive research. Data were collected through field observations, interviews, and document studies. The data that has been collected was analyzed descriptively qualitatively. The results of the Ecotourism Research Lembu Putih Taro show: (1) it can be used as a biology learning content in terms of biological material (taxonomy, genetics, morphology/animal physiology, ecology) and the local wisdom context in it; (2) the original environment as a learning media based on local wisdom that is feasible to apply because it has various advantages including being original/real and contextual media so that it is able to provide direct experience so that information is easier to understand and more memorable, fosters students' love for local wisdom very useful culture, participating in the preservation of local wisdom, indirectly participating in practicing religious teachings, and increasing students' scientific learning abilities. The implication of this research is Ecotourism Lembu Putih Taro Village as content and learning media is expected to create a more meaningful learning process.

Keywords: Taro White Ox ecotourism, local wisdom

\begin{tabular}{|c|c|c|}
\hline \multicolumn{2}{|l|}{ History: } & Publisher: Undiksha Press \\
\hline Received & : 02 Januari 2021 & Licensed: This work is licensed under \\
\hline Revised & : 15 Januari 2021 & a Creative Commons Attribution 4.0 License \\
\hline Accepted & : 23 Mei 2021 & (c) (7) () \\
\hline Published & : 25 Juli 2021 & (2) ${ }_{\mathrm{EY}} \mathrm{SA}_{\mathrm{SA}}$ \\
\hline
\end{tabular}

\section{Pendahuluan}

Pelajaran Biologi merupakan pelajaran yang menarik, bermakna dan menyenangkan serta berkaitan dengan kehidupan sehari-hari (Firman \& Rahman, 2020; Puspitasari, 2019). Pembelajaran Biologi dapat terlaksana dengan baik dan tercapainya tujuan pembelajaran 
yang maksimal maka siswa harus dapat memahami konsep-konsep materi yang diberikan guru pada saat proses pembelajaran (Ayu Renita, 2020; Maulana, 2021). Pengetahuan dan pemahaman yang telah dimiliki siswa akan membantu mengembangkan kreativitasnya. Selain itu ketersedian sarana dan prasarana seperti media pembelajaran yang digunakan dalam proses pembelajaran juga membantu siswa untuk memahami konsep (Andriyani \& Suniasih, 2021; Paramita et al., 2016). Pemanfaatan media merupakan salah satu dari sekian banyak masalah dalam pembelajaran di sekolah. Pengimplementasian metode dan media pembelajaran yang digunakan dalam pembelajaran Biologi dapat meningkatkan pemahaman konsep dan kreativitas siswa (Hetzel et al., 2021; Rasyid et al., 2016). Selain penggunaan media, ketepatan memilih metode pembelajaran dalam setiap proses belajar mengajar akan menentukan tujuan pembelajaran yang telah direncanakan dan peningkatan kemampuan akademik serta non akademik siswa, sehingga akan diikuti meningkatnya pemahaman konsep yang diberikan dan kreativitas siswa dalam pembelajaran.

Permasalahan saat ini, akibat adanya pandemi Covid-19 proses pembelajaran memiliki resiko tingkat partisipasi siswa yang rendah terkait tatap muka langsung antara guru dan murid. Dibutuhkan peran guru dalam mengemas dan mengelola pembelajaran daring agar materi yang disampaikan bisa ditangkap dengan baik oleh siswa (Anugrahana, 2020; Ota et al., 2021; Wahyono et al., 2020). Banyak guru yang belum mengintegrasikan kearifan lokal dalam pembelajaran sehingga tujuan pendidikan belum tercapai selain itu belum mengenal kearifan lokal di lingkungannya (Chairiyah, 2017; Rahman et al., 2019).Untuk mengatasi beberapa permasalahan tersebut diperlukan media pembelajaran yang menyenangkan, inovatif dan kreatif. Media pembelajaran sebagai media yang mampu menggeser pembelajaran yang membosankan menjadi pembelajaran yang menyenangkan. Media yang dikembangkan adalah media yang interaktif dalam pembelajarannya dapat meningkatkan motivasi belajar siswa (Agustiana \& Rusmana, 2018; Kuswanto et al., 2017). Adanya media pembelajaran dapat menunjang proses pembelajaran menjadi lebih efektif(Crismono, 2017; Putri, 2017).

Temuan penelitian sebelumnya menyatakan betapa pentingnya pengintegrasian kearifan lokal dalam pembelajaran sebagai upaya menciptakan pembelajaran yang bukan hanya membekali siswa pengetahuan saja tetapi juga menanamkan rasa cinta terhadap keberagaman lokal dilingkungannya (Prayogi et al., 2019; Widodo, 2020). Integrasi kearifan lokal dalam pembelajaran khususnya pembelajaran daring dapat dilakukan dengan memasukkan kearifan lokal sebagai konten pembelajaran (Indrawan, et al, 2019; Indrawan et al., 2020). Sapi Taro merupakan salah satu alternatif konten kearifan lokal Desa Taro yang dapat diintegrasikan sebagai bagian dari materi biologi. Kearifan lokal menjadi sangat penting mengingat bahwa proses pembelajaran yang terjadi di kelas, sebaiknya dimulai dengan dunia terdekat atau yang sering dijumpai oleh siswa (Khusna et al., 2018). Nilai-nilai kearifan lokal akan membantu siswa dalam memahami setiap konsep dalam materi sehingga bekal pengetahuan yang diperoleh siswa tidak hanya sampai pada sebatas pengetahuan saja, tetapi juga dapat diimplementasikan siswa dalam wujud praktik di luar sekolah.

Berdasarkan hasil observasi dan wawancara dengan pengelola Ekowisata Lembu Putih yang berada di Desa Taro Gianyar Bali diperoleh informasi bahwa ekowisata tersebut memiliki potensi untuk dijadikan konten media pembelajaran khususnya media pembelajaran biologi berbasis kearifan lokal. Penelitian ini memiliki nilai tambah karena potensi-potensi yang digali merupakan potensi kearifan lokal Hindu Bali melalui Ekowisata Lembu Putih Desa Taro. Tujuan penelitian ini adalah menganalisis potensi Ekowisata Lembu Putih Taro sebagai konten media pembelajaran biologi berbasis Kearifan Lokal Hindu Bali. Adanya penelitian ini diharapkan mampu menjadi referensi dalam pemilihan media pembelajaran berbasis kearifan lokal Hindu Bali. Sehingga peserta didik tidak hanya berkompeten secara ilmiah tetapi juga menumbuhkan kecintaan pada kearifan lokal budayanya yang luar biasa. 


\section{Metode}

Metode yang digunakan dalam penelitian ini adalah metode penelitian deskriptif eksploratif yang berusaha mendeskripsikan suatu gejala atau peristiwa secara mendetail. Pengumpulan data dilakukan melalui observasi, wawancara dan studi dokumen. Pertama observasi, setelah pembagian tugas, masing-masing tim peneliti melakukan observasi di kawasan Ekowisata Lembu Putih Desa Taro. Observasi yang dilakukan di sini adalah observasi naturalistik yaitu penelitian yang dilakukan dalam konteks atau seting lingkungan yang sesungguhnya. Wawancara yang dilakukan adalah wawancara bebas dan terbuka, pertanyaan diberikan secara spontan sesuai situasi dan kondisi di lapangan serta dengan jawaban yang tidak terikat. Ketiga studi dokumen, yang dilakukan dengan mengkaji dokumen-dokumen terkait Ekowisata Lembu putih Desa Taro. Dokumen yang digunakan adalah buku, jurnal-jurnal hasil penelitian terkait dan lampiran peraturan menteri pendidikan dan kebudayaan nomor 67, 68,69, dan 70 tahun 2013 tentang kerangka dasar dan struktur kurikulum SD, SMP, SMA dan SMK. Data yang telah terkumpul nantinya dianalisis secara deskriptif kualitatif. Penyajian data dilakukan dengan mendeskripsikan seluruh temuan yang dilengkapi dengan tabel dan gambar. Dengan demikian akan terlihat gambaran secara rinci tentang potensi-potensi Ekowisata Lembu Putih Taro sebagai media pembelajaran biologi yang cocok untuk materi-materi tertentu.

\section{Hasil dan Pembahasan \\ Hasil Penelitian}

Berdasarkan hasil analisis, didapat berbagai potensi dari Ekowisata Lembu Putih Desa Taro dapat digunakan sebagai konten media pembelajaran khususnya biologi. Secara rinci potensi-potensi konten pembelajaran biologi tersebut dapat jabarkan seperti yang tampak pada Tabel 1.

Tabel 1. Potensi Konten Pembelajaran Biologi Ekowisata Lembu Putih Desa Taro

\begin{tabular}{|c|c|c|c|}
\hline No & $\begin{array}{l}\text { Potensi Sebagai } \\
\text { Sumber Media }\end{array}$ & $\begin{array}{c}\text { Materi Pelajaran Yang } \\
\text { Sesuai }\end{array}$ & Foto \\
\hline 1 & $\begin{array}{l}\text { Keberadaan lembu } \\
\text { putih }\end{array}$ & $\begin{array}{l}\text { - Kelainan albinisme } \\
\text { - Genetika albinisme } \\
\text { - Morfologi hewan } \\
\text { albinisme } \\
\text { - Rantai makanan } \\
\text { - Klasifikasi } \\
\text { organisme }\end{array}$ & \\
\hline
\end{tabular}




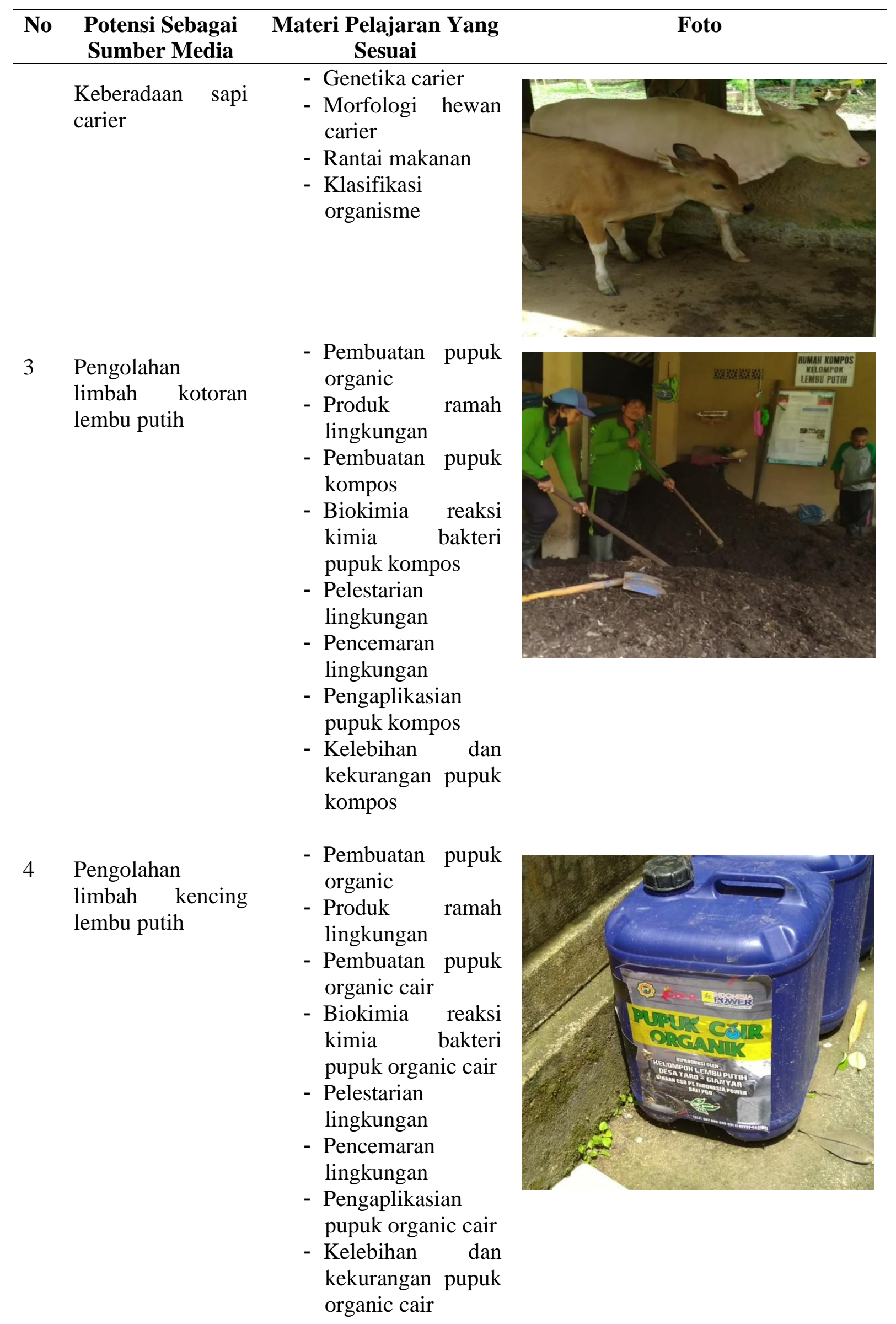




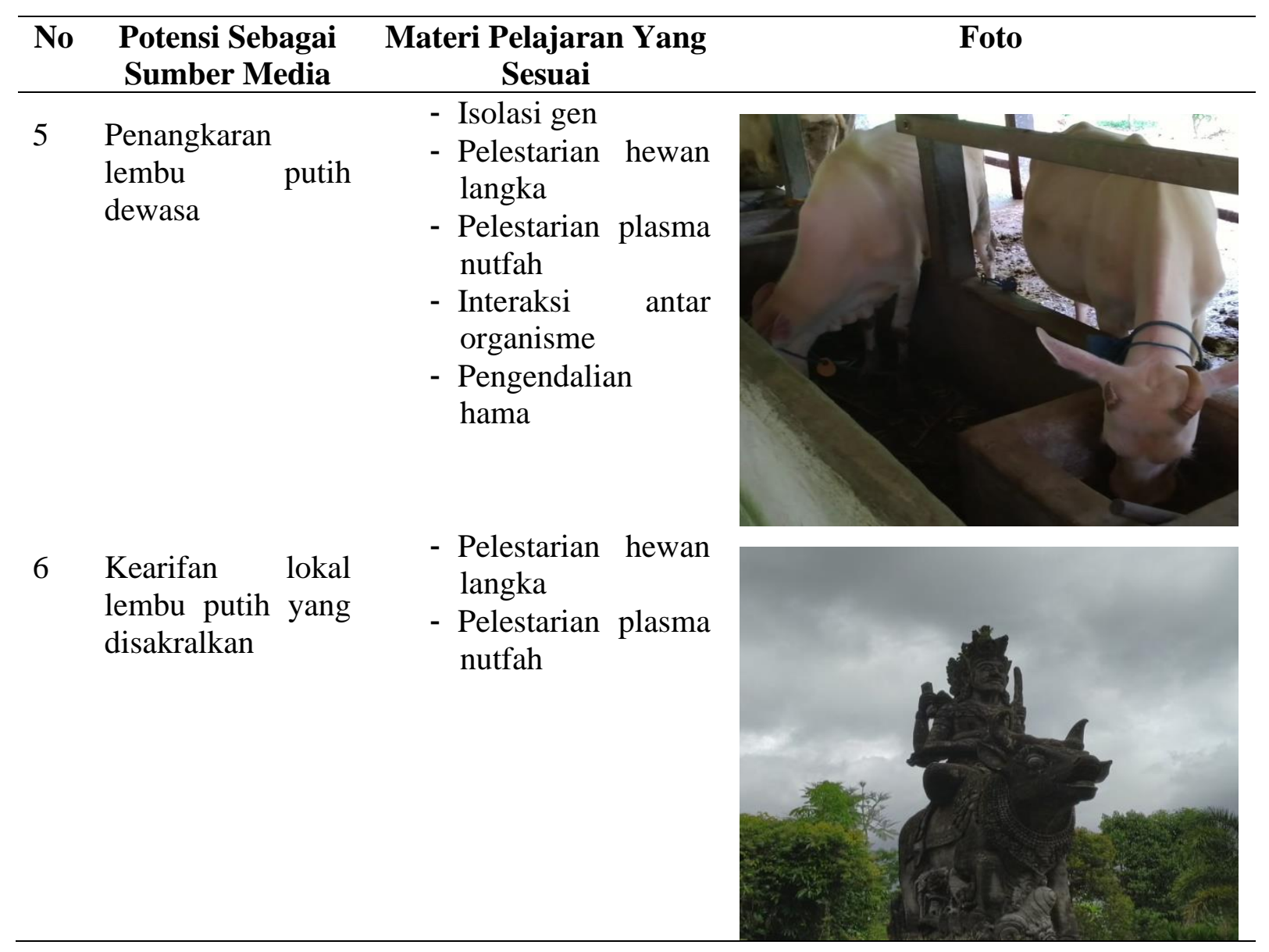

Berdasarkan hasil wawancara dengan pengelola Ekowisata Lembu Putih Desa Taro diperoleh informasi bahwa pada saat ada kunjungan dari siswa, mahasiswa maupun masyarakat, biasanya melaksanakan observasi langsung untuk memperjelas informasi. Ekowisata Lembu Putih Desa Taro sebagai konten media pembelajaran mampu memberikan pemahaman holistik tentang klasifikasi (bagian dari materi taksonomi dan morfologi hewan), kekhasan genetik (bagian dari materi genetika dan morfologi hewan), proses pemeliharaan (sebagai bagian materi ekologi hewan dan fisiologi hewan), pemanfaatan limbah kotoran dan kencing (dapat digunakan sebagai bagian konten ekologi dan holtikultura). Sedangkan, nilai sakral dari Lembu Putih Desa Taro sebagai integrasi kearifan lokal dalam pembelajaran biologi sebagai konteks dengan mitologi lokal Desa Taro. Siswa dan mahasiswa dapat informasi baru yang jelas dan holistik dapat melalui media atau berkunjung secara langsung ke ekowisata tersebut sebagai pengayaan materi biologi. Hal ini menunjukkan potensi lingkungan Ekowisata Lembu Putih Desa Taro tersebut secara langsung dapat digunakan sebagai media pembelajaran biologi yang kontekstual. Lingkungan sebagai media pembelajaran biologi adalah alternatif yang sangat menarik, karena pembelajaran langsung di habitat aslinya membuat siswa dan mahasiswa dapat memperlajari materi biologi melalui berwisata atau dalam istilah bali melali sambil melajah. 


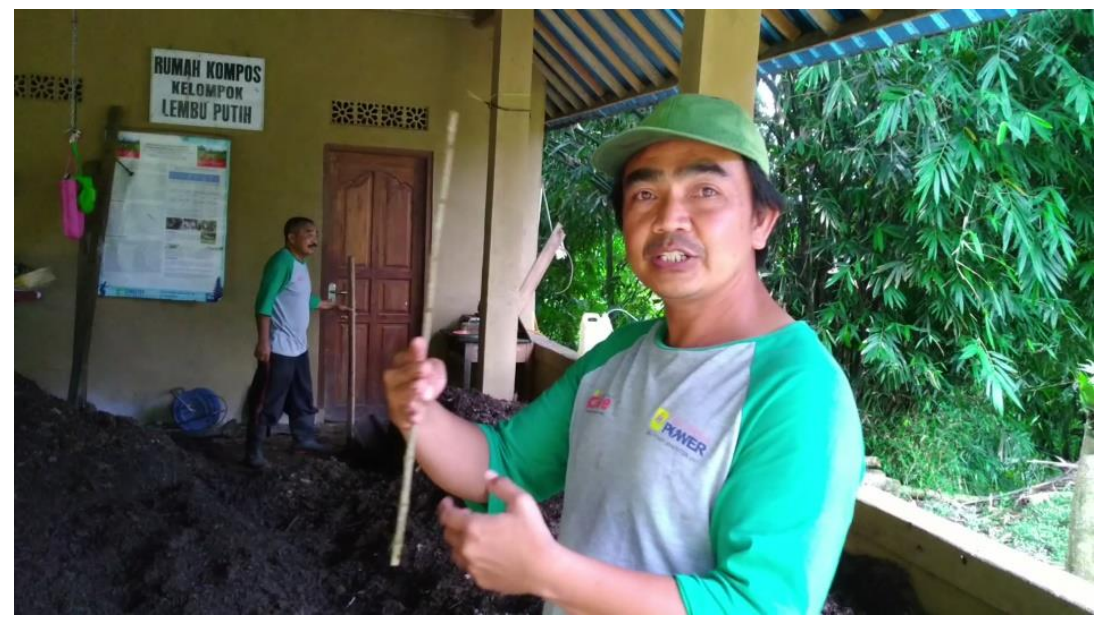

Gambar 1. Wawancara Dengan Salah Satu Pengelola

\section{Pembahasan Hasil Penelitian}

Berdasarkan hasil penelitian menunjukan Ekowisata Lembu Putih Desa Taro dapat digunakan sebagai konten pembelajaran dan lingkungan asli sebagai media pembelajaran biologi. Konten pembelajaran Ekowisata Lembu Putih Desa Taro dapat dikembangkan dengan membahas genetika (fenotipe dan genotipe), morfologi, fisiologi, lingkungan/habitat, nilai pelestarian yang jenis dalam ekologi, dan teknologi pengelolaan limbah kotoran dan kencing sapi taro untuk bidang pertanian dan nilai keramahan lingkungan. Sebagai media pembelajaran lingkungan Ekowisata Lembu Putih Desa Taro dapat dikunjungi secara langsung oleh siswa atau mahasiswa yang mempelajari biologi, sehingga memperoleh pengalaman belajar langsung melalui proses observasi dan wawancara dengan pengelola ekowisata tersebut.

Konten pembelajaran Sapi Taro sebagai konten pembelajaran biologi memiliki beberapa ciri fenotipik khas yang membedakannya dengan sapi Bali pada umumnya, yaitu: pada umumnya bulu berwarna putih, kulit albino, iris mata dan kuku berwarna pucat atau bening, warna tanduk dan teracak lebih pucat daripada sapi Bali biasa,dan tidak tahan terhadap sinar matahari secara langsung. Selain itu, ciri-ciri khas tersebut, pada sapi Taro juga terdapat ciri-ciri yang sama dengan ciri khas yang dimiliki oleh sapi Bali pada umumnya, yakni warna putih berbentuk oval yang khas pada pantat dan tungkai bagian bawahnya. Kekhasan konten Sapi Taro dapat digunakan menstimulasi meningkatkan kemampuan belajar saintifik siswa dan mahasiswa melalui proses observasi, menanya melalui proses wawancara, menggali informasi yang lebih luas, mencari persamaan dan perbedaan karakteristik dengan sapi lain dan habitatnya, mengasosiasikan informasi yang diperolehnya, dan mengkomunikasikannya dapat berupa laporan, grup diskusi berfokus, dan atau presentasi sebagai pendukung pembelajaran K-13. Peningkatan kemampuan belajar dengan saintifik mampu meningkatkan hasil belajar, kreativitas, dan kemampuan berpikir kritis peserta didik (Gozali, 2017; Machin, 2014).

Lingkungan Ekowisata Lembu Putih Desa Taro dengan ekologi, sistem pengelolaan, dan nilai kultural masyarakatnya menjadikanya sebagai media pembelajaran biologi dengan konsep melali sambil melajah, sehingga pembelajaran lebih bermakna. Pembelajaran bermakna adalah suatu proses pembelajaran dimana informasi baru dihubungkan dengan struktur pengertian yang sudah dimiliki seorang yang sedang dalam proses pembelajaran (Najib, 2016; Setyowati \& Mawardi, 2018). Pembelajaran bermakna terjadi bila siswa mencoba menghubungkan fenomena baru ke dalam struktur pengetahuan mereka. Artinya, 
bahan pelajaran itu harus cocok dengan kemampuan peserta didik dan harus relevan dengan struktur kognitif yang dimiliki peserta didik. Oleh karena itu, pelajaran harus dikaitkan dengan konsep-konsep yang sudah dimiliki peserta didik, sehingga konsep-konsep baru tersebut benar-benar terserap olehnya. Berdasarkan hal tersebut, sangat layak Lingkungan Ekowisata Lembu Putih Desa Taro digunakan sebagai media pembelajaran asli yang dapat menstimulasi pembelajaran yang holistik dan bermakna bagi peserta didik.

Penelitian sebelumnya menunjukkan bahwa konten pembelajaran biologi pada kearifan lokal Ekowisata Lembu Putih Desa Taro antara lain berkaitan dengan: 1) distribusi dan pelestarian lahan pertanian terkait adanya system upah lahan untuk para pengelola yang harus dikelola dan tidak boleh dijual dan dibanguni bangunan, 2) mekanisme pengendalian hama karena lembu putih yang hidup liar berdampingan dengan lahan penduduk berpotensi besar menjadi hama, dan 3) mekanisme pemurnian genetika satwa lembu putih. Semua manfaat Ekowisata Lembu Putih Desa Taro tersebut pada nantinya dapat dijadikan media pembelajaran pada 3 materi tersebut (Kuswarno et al., 2019). Lembu Putih Desa Taro merupakan lembu albino yang sudah banyak dipelajari dalam bidang genetika. Ini artinya peluang yang besar lembu putih Desa Taro sebegai konten dan media asli dalam pembelajaran biologi khususnya bidang genetika terkait kelainan albinisme.

Di samping itu, lingkungn Ekowisata Lembu Putih Desa Taro sebagai media pembelajaran biologi memiliki berbagai keunggulan. Pertama, menjadikan Ekowisata Lembu Putih Desa Taro sebagai media pembelajaran dapat memberikan keuntungan pada peserta didik karena media tersebut tergolong media asli yang mampu memberikan pengalaman nyata kepada mereka. Keunggulan kedua pemanfaatan Ekowisata Lembu Putih Desa Taro sebagai media pembelajaran adalah sekaligus memberikan wawasan yang holistic kepada peserta didik akan pengetahuan ilmiah dan kearifan lokal budayanya. Dengan mengenal dan memahami bahwa kearifan lokal Hindu Bali yang sangat beragam tidak hanya terkait dengan kehidupan keagamaan, tetapi juga sangat bermanfaat dan relevan dalam bidang pendidikan. Dengan demikian, media pembelajaran berbasis kearifan lokal seperti ini hendaknya digali dan dimanfaatkan karena mampu secara langsung bermanfaat dalam dunia pendidikan dan secara tidak langsung turut serta dalam melestarikan kearifan lokal budaya serta pengamalan ajaran agama khususnya agama hindu Bali.

Implikasi dari temuan dan hasil penelitian potensi Ekowisata Lembu Putih Desa Taro sebagai konten dan media pembelajaran biologi diharapkan dapat menciptakan pembelajaran bermakna bagi peserta didik. Sebagai konten maupun media pembelajaran Ekowisata Lembu Putih Desa Taro dapat menstimulasi peserta didik untuk mengaitkan informasi yang diperolehnya dengan pengetahuan biologi relevan dalam struktur kognitif berupa berbagai fakta, konsep, dan generalisasi yang telah dimilikinya. Peserta didik dapat mengasosiasikan fenomena Lembu Putih Desa Taro ke dalam struktur pengetahuan biologi yang dimilikinya.

\section{Simpulan}

Kearifan lokal Ekowisata Lembu Putih Desa Taro berpotensi besar digunakan sebagai konten pembelajaran dan lingkungan sebagai media pembelajaran asli khususnya pembelajaran biologi. Berdasarkan hasil dan pembahasan dapat disimpulkan antara lain: (1) dapat digunakan sebagai konten pembelajaran biologi ditinjau dari materi biologi (taksonomi, genetika, morfologi/fisiologi hewan, ekologi) dan konteks kearifan lokal yang ada di dalamnya; dan (2) lingkungan asli sebagai media pembelajaran berbasis kearifan lokal yang layak untuk diterapkan karena memiliki berbagai keunggulan di antaranya adalah sebagai media asli/nyata dan kontekstual sehingga mampu memberikan pengalaman langsung sehingga informasi lebih mudah dipahami dan lebih diingat, menumbuhkan kecintaan peserta 
didik akan kearifan lokal budayanya yang sangat bermanfaat, turut serta dalam upaya pelestarian kearifan lokal, secara tidak langsung turut serta dalam mengamalkan ajaran agama, dan meningkatkan kemampuan belajar saintifik peserta didik. Implikasi penelitian ini Ekowisata Lembu Putih Desa Taro sebagai konten dan atau media pembelajaran diharapkan dapat menciptakan proses pembelajaran yang lebih bermakna.

\section{Daftar Rujukan}

Agustiana, L., \& Rusmana, I. M. (2018). Pemanfaatan Microsoft Power Point sebagai Alternatif Media. Prosiding Seminar Dan Diskusi Nasional Pendidikan Dasar, 374379. http://journal.unj.ac.id/unj/index.php/psdpd/article/view/10164.

Andriyani, N. L., \& Suniasih, N. W. (2021). Development Of Learning Videos Based On Problem-Solving Characteristics Of Animals And Their Habitats Contain in Science Subjects On 6th-Grade. Journal of Education, 5(1), 37-47. https://doi.org/http://dx.doi.org/10.23887/jet.v5i1.32314.

Anugrahana, A. (2020). Hambatan, Solusi dan Harapan : Pembelajaran Daring Selama Masa Pandemi Covid-19 Oleh Guru Sekolah Dasar. Jurnal Pendidikan Dan Kebudayaan, 10(3), 282-289. https://doi.org/10.24246/j.js.2020.v10.i3.p282-289.

Ayu Renita. (2020). Pengembangan Ensiklopedia Tumbuhan Paku Sebagai Sumber Belajar Keanekaragam Hayati. Jurnal Biologi Dan Pembelajarannya (JB\&P), 7(1), 1-6. https://doi.org/10.29407/jbp.v7i1.14797.

Chairiyah. (2017). Implementasi Pendidikan Karakter melalui Nilai-nilai Kearifan Lokal di SD Taman Siswa Jetis Yogyakarta. Jurnal Pendidikan Ke-SD-An, 4(1), 208-215. https://doi.org/http://dx.doi.org/10.30738/trihayu.v4i1.2116.

Crismono, P. C. (2017). Pengaruh Outdoor Learning Terhadap Kemampuan Berpikir Kritis Matematis Siswa The Influence Of Outdoor Learning On The Mathematical Critical Thinking Skills Of Students. Junal Pendidikan Matematika Dan Sains, 4(2), 106-113. http://journal.uny.ac.id/index.php/jpms Jurnal.

Firman, \& Rahman, S. R. (2020). Pembelajaran Online di Tengah Pandemi Covid-19 Firman1, Sari Rahayu Rahman1. Indonesian Journal of Educational Science (IJES), 2(2), 81-89.

Gozali, I. (2017). Pendekatan Scientific Learning Dalam Meningkatkan Prestasi Belajar Siswa. Pedagogik Jurnal Pendidikan, 4(1), 1-13. doi:https://doi.org/10.33650/pjp.v4i1.5

Hetzel, L., S.Fischer, D., Günnemann, S., \& Fabian J.Theis. (2021). Graph representation learning for single-cell biology. Current Opinion in Systems Biology. https://doi.org/10.1016/j.coisb.2021.05.008.

Indrawan, I P. O., Pramana, M. I., \& Gunawan, K. D. H. (2019). Developing Tri Kaya Parishuda Based Blended Learning Media Using Adobe Captive for Probstat Courses. Journal of Educational Research and Evaluation, 3(3), 157-171. doi:http://dx.doi.org/10.23887/jere.v3i3.21858

Indrawan, I P. O., Saskara, G.A.J. \& Wijaya, I K. M. W. B. (2019). Kreativitas dan Motivasi Belajar Mahasiswa dalam Implementasi Blended Learning Berbasis Bali. . International Journal of Natural Sciences and Engineering, 3(2), 70-78. doi:http://dx.doi.org/10.23887/ijnse.v3i2.22194 
Indrawan, I P.O., Suwardika, G., Jaya, A.A.N.A \& Wijaya, I K.W.B. (2020). Integrasi Pembelajaran IPA dalam Pemebelajaran Berbasis Teknologi. Webinar Nasional Mengimplementasikan Merdeka Belajar (pp. 61-65). Singaraja: UNDIKSHA PRESS.

Khusna, N., Shufa, F., \& Artikel, S. (2018). Pembelajaran Berbasis Kearifan Lokal Di Sekolah Dasar: Sebuah Kerangka Konseptual. Inopendas Jurnal Ilmiah Kependidikan, 1(1), 48-53. https://doi.org/10.24176/jino.v1i1.2316.

Kuswanto, J., Walusfa, Y., Artikel, S., Korespondensi, A., Ratu Penghulu No, J., Sari, K., Baru, T., Raja Tim, B., Ogan Komering Ulu, K., \& Selatan, S. (2017). Pengembangan Multimedia Pembelajaran pada Mata Pelajaran Teknologi Informasi dan Komunikasi Kelas VIII. Innovative Journal of Curriculum and Educational Technology IJCET, 6(2), 58-64.

Kuswarno, E., Qurratul, A., Budaya, M., Windasari, A., Al, M., Mubah, A. S., SARININGSIH, S., Dharma, S., Strike, M., Ã, W. J., Saptari, R., Salah, M., Syarat, S., Kusumawardhana, M., Yunita, D., Indrawati, N., Sahadi, S., Ira Rahayu, Todorov, T., ... Rahmawati, I. (2019). Kearifan Lokal Di Balik Mitos Lembu Putih Di Desa Taro , Gianyar. Harmonia - Journal of Arts Research and Education, 1(1), 430-440. http://journal.wima.ac.id/index.php/ARETE/article/view/166/161\%0Ahttp://journal2. um.ac.id/index.php/jbs/article/view/127/100\%0Ahttp://orvillejenkins.com/whatiscultu re/greetingscul.html\%0Ahttp://puslit2.petra.ac.id/ejournal/index.php/ars/article/view/ 16354

Machin, A. (2014). Implementasi Pendekatan Saintifik, Penanaman Karakter Dan Konservasi Pada Pembelajaran Materi Pertumbuhan. Jurnal Pendidikan IPA Indonesia, 3 (1), 28 35. doi:https://doi.org/10.15294/jpii.v3i1.2898

Maulana, M. A. (2021). Efektivitas Pembelajaran Daring Terhadap Hasil Belajar Biologi Pada Konsep Biodiversitas Di Kelas X Ipa Ma Muhammadiyah Salaka Kabupaten Takalar. Jurnal Riset Dan Inovasi Pembelajaran, 1(1), 85-95. https://doi.org/10.51574/jrip.v1i1.22.

Najib, D. A. dan E. (2016). Pengaruh Penerapan Pembelajaran Bermakna (Meaningfull Learning) Pada Pembelajaran Tematik IPS Terpadu Terhadap Hasil Belajar Siswa Kelas III di MI Ahliyah IV Palembang. Jurnal PGMI, 2(1), 19-28. http://jurnal.radenfatah.ac.id/index.php/jip/article/view/1063.

Ota, M. K., Djou, A. M. G., \& Numbah, F. F. (2021). Problematika Pembelajaran Daring Siswa Kelas Vii Smpn. Jurnal Pengabdian Masyarakat, 2(1), 74-81. https://doi.org/10.37478/mahajana.v2i1.769.

Paramita, D. K., Garminah, \& Wibawa, I. M. C. (2016). Penerapan Model Pembelajaran Kooperatif Tipe NHT Berbantuan Media Audio Visual Untuk Meningkatkan Hasil Belajar IPA. Mimbar PGSD Undiksha, 4(1), 1-10. https://doi.org/http://dx.doi.org/10.23887/jjpgsd.v4i1.6954.

Prayogi, D. S., Utaya, S., \& Sumarmi, S. (2019). Internalisasi Kearifan Lokal Dalam Pembelajaran melalui Pengembangan Multimedia Interaktif Muatan Pembelajaran IPS. Jurnal Pendidikan: Teori, Penelitian, Dan Pengembangan, 4(11), 1457-1463.

Puspitasari, S. (2019). Upaya Meningkatkan Hasil Belajar Ipa Dengan Menggunakan Model Pembelajaran Think Pair Share. Global Edukasi, 3(1), 55-60. http://jurnal.goretanpena.com/index.php/JGE.

Putri, W. N. (2017). Pengaruh Media Pembelajaran Terhadap Motivasi Belajar Bahasa Arab Siswa Madrasah Tsanawiyah. LISANIA: Journal of Arabic Education and Literature, 1(1), 1-16. https://doi.org/10.18326/lisania.v1i1.1160.

Rahman, E. S., Sari, T. T., \& Meita, N. M. (2019). Pengembangan Buku Saku Tematik Sd Berbasis Kearifan Budaya Lokal. Jurnal Pendidikan Dasar, 3(2), 70-78. https://doi.org/10.24929/alpen.v3i2.28. 
Rasyid, M., Azis, A., \& Saleh, A. (2016). Pengembangan Media Pembelajaran Berbasis Multimedia Dalam Konsep Sistem Indera Pada Siswa Kelas XI SMA. Jurnal Pendidikan Biologi, 7(2), 69-80. https://doi.org/10.17977/um052v7i2p69-80.

Setyowati, N., \& Mawardi, M. (2018). Sinergi Project Based Learning dan Pembelajaran Bermakna untuk Meningkatkan Hasil Belajar Matematika. Scholaria: Jurnal Pendidikan Dan Kebudayaan, 8(3), 253-263. https://doi.org/10.24246/j.js.2018.v8.i3.p253-263.

Wahyono, P., Husamah, H., \& Budi, A. S. (2020). Guru profesional di masa pandemi COVID-19: Review implementasi, tantangan, dan solusi pembelajaran daring. Jurnal Pendidikan Profesi Guru, 1(1), 51-65. https://doi.org/https://doi.org/10.22219/jppg.v1i1.12462.

Widodo, A. (2020). Nilai Budaya Ritual Perang Topat Sebagai Sumber Pembelajaran IPS Berbasis Kearifan Lokal di Sekolah Dasar. Gulawentah:Jurnal Studi Sosial, 5(1), 1. https://doi.org/10.25273/gulawentah.v5i1.6359. 